\title{
Physicochemical Characteristics of Water Samples Collected from River Sokoto, Northwestern Nigeria
}

\author{
M. I. O. Raji ${ }^{*}$, Y. K. E. Ibrahim², B. A. Tytler², J. O. Ehinmidu² \\ ${ }^{1}$ Department of Pharmaceutics and Pharmaceutical Microbiology, Usmanu Danfodiyo University, Sokoto, \\ Nigeria \\ ${ }^{2}$ Department of Pharmaceutics and Pharmaceutical Microbiology, Ahmadu Bello University, Zaria, Nigeria \\ Email: ${ }^{*}$ rajimuda@gmail.com
}

Received 19 April 2015; accepted 1 June 2015; published 4 June 2015

Copyright (C) 2015 by authors and Scientific Research Publishing Inc.

This work is licensed under the Creative Commons Attribution International License (CC BY). http://creativecommons.org/licenses/by/4.0/

c) (i) Open Access

\section{Abstract}

Physicochemical parameters of surface water collected from six different points (P1 to P6) on River Sokoto were analysed during January (Dry Season) and August (Rainy Season), 2014 to determine its water quality using standard methods. The highest temperature of $25.6^{\circ} \mathrm{C}$ was recorded by $P 1$ in dry season while $P 5$ recorded the highest value of $29.2^{\circ} \mathrm{C}$ in rainy season. All the water samples were alkaline in dry season with the highest $\mathrm{pH}$ value of 8.50 in $\mathrm{P5}$ and the least value of 8.02 in $\mathrm{P} 6$ whereas in rainy season, $\mathrm{P1}, \mathrm{P2}$ and $\mathrm{P} 3$ were slightly acidic while P5 and P6 were slightly neutral and $P 4$ alkaline. The highest values of $510 \mu \mathrm{S} / \mathrm{cm}$ and $850.3 \mathrm{mg} / \mathrm{l}$ were recorded from $P 4$ for electrical conductance and hardness respectively in the rainy season whereas in dry season, $P 5$ and $P 4$ had the highest values of $321 \mu \mathrm{S} / \mathrm{cm}$ and $282.8 \mathrm{mg} / \mathrm{l}$ respectively. The highest $D O$ and BOD levels in dry season were $1.7 \mathrm{mg} / \mathrm{l}$ and $0.7 \mathrm{mg} / \mathrm{l}$ respectively in $P 1$ and the least values were $0.7 \mathrm{mg} / \mathrm{l}$ and $0.2 \mathrm{mg} / \mathrm{l}$ respectively in P5. But in the rainy season, P6 recorded the highest DO value of $0.1 \mathrm{mg} / \mathrm{l}$ while $\mathrm{P} 2$ and $P 5$ recorded the least value of $0.07 \mathrm{mg} / \mathrm{l}$. For BOD, P5 had the highest value $(2.13 \mathrm{mg} / \mathrm{l})$ while $\mathrm{P} 3 \mathrm{had}$ the least value $(0.20 \mathrm{mg} / \mathrm{l})$. For COD, the highest value (230 $\mathrm{mg} / \mathrm{l})$ was found in P4 and $\mathrm{P} 6$ and the least value $(30 \mathrm{mg} / \mathrm{l})$ was found in P1 in dry season while in the rainy season, P2 had the highest COD value $(1008 \mathrm{mg} / \mathrm{l})$ and $P 4$ had the least value of $32 \mathrm{mg} / \mathrm{l}$. TDS and TSS values generally were higher in the rainy season than in the dry season due to higher amount of floating particles in the rainy season. While P1 and P6 recorded the highest values (800 $\mathrm{mg} / \mathrm{l}$ and $700 \mathrm{mg} / \mathrm{l}$ respectively) in the rainy season, $P 4$ recorded the least value of $100 \mathrm{mg} / \mathrm{l}$ in both seasons. The highest Chloride level was found in P4 in the dry $(100 \mathrm{mg} / \mathrm{l})$ and rainy $(180$ $\mathrm{mg} / \mathrm{l})$ seasons with the least level in P2 (35 mg/l) in dry season and in P1 and P2 with the least level of $60 \mathrm{mg} / \mathrm{l}$ in the rainy season. The highest concentration of Sulphate in P1 $(220 \mathrm{mg} / \mathrm{l})$ in dry

\footnotetext{
*Corresponding author.
}

How to cite this paper: Raji, M.I.O., Ibrahim, Y.K.E., Tytler, B.A. and Ehinmidu, J.O. (2015) Physicochemical Characteristics of Water Samples Collected from River Sokoto, Northwestern Nigeria. Atmospheric and Climate Sciences, 5, 194-199. 
season was far above the highest concentration $(124 \mathrm{mg} / \mathrm{l})$ in the rainy season whereas highest concentration of Nitrate in dry season in P1 (19.7 mg/l) was somehow below the highest concentration in rainy season in $\mathrm{P4}(28.1 \mathrm{mg} / \mathrm{l})$. Phosphate and Ammonia had the highest values of 1.77 $\mathrm{mg} / \mathrm{l}$ and $0.84 \mathrm{mg} / \mathrm{l}$ respectively in $\mathrm{P5}$ in dry season while in rainy season, $\mathrm{P} 6$ and $\mathrm{P} 4$ had the highest values of $0.22 \mathrm{mg} / \mathrm{l}$ and $1.20 \mathrm{mg} / \mathrm{l}$ respectively. There was significant seasonal variation in some physicochemical parameters and most of the parameters were within permissible limits, thus, making the water suitable for irrigation purposes.

\title{
Keywords
}

\author{
River Sokoto, Seasonal Variation, Dry Season, Rainy Season, Elemental Constituents, \\ Concentration
}

\section{Introduction}

Water is an essential component of the environment and it sustains life on the earth. Human beings depend on water for their survival. Water is also a raw material for photosynthesis and therefore, is important for crop production [1].

The availability of good quality water is an indispensable feature for preventing diseases and improving quality of life. Natural water contains different types of impurities are introduced in to aquatic system by different ways such as weathering of rocks and leaching of soils, dissolution of aerosol particles from the atmosphere and from several human activities, including mining, processing and the use of metal based materials [2].

The increased use of metal-based fertilizer in agricultural revolution of the government could result in continued rise in concentration of metal pollutions in fresh water reservoir due to the water run-off. Also faecal pollution of drinking water causes water born disease which has led to the death of millions of people [3].

People on globe are under tremendous threat due to undesired changes in the physical, chemical and biological characteristics of air, water and soil. These are related to animal and plants and finally affecting on them [4]. Industrial development (either new or existing industry expansion) results in the generation of industrial effluents, and if untreated results in water, sediment and soil pollution [5] [6].

High levels of pollutants in river water systems causes an increase in biological oxygen demand (BOD), chemical oxygen demand (COD), total dissolved solids (TDS), total suspended solids (TSS), toxic metals such as $\mathrm{Cd}, \mathrm{Cr}, \mathrm{Ni}$ and $\mathrm{Pb}$ and faecal coliform and hence make such water unsuitable for drinking, irrigation and aquatic life.

Industrial effluent contamination of natural water bodies has emerged as a major challenge in developing and densely populated countries like Nigeria. Estuaries and inland water bodies, which are the major sources of drinking water in Nigeria, are often contaminated by the activities of the adjoining populations and industrial establishments [7].

This is because river systems are the primary means for disposal of waste, especially the effluents, from industries that are near them. These effluents from industries have a great deal of influence on the pollution of the water body, due to its ability to alter the physical, chemical and biological nature of the receiving water body [8]. Increased industrial activities have led to pollution stress on surface waters both from industrial, agricultural and domestic sources [9].

River Sokoto is situated adjacent to the industrial area of the metropolis where industries such as cement, aluminum, fertilizer, foam and tanning factories are found. Most of these factories discharged their effluents into the environment and such discharge end up flowing into the river.

River Sokoto serves as source water for the water treatment plant that supplies pipe-borne water needs of the people in the metropolis. The river is also dredged for sand for use in the local building construction and molding of blocks for modern constructions. Other uses to which the river is employed which include industrial, agricultural, domestic and recreational purposes could pose serious health and environment hazards to the community. Thus, the need to study the physicochemical characteristics of River Sokoto to determine the quality of its water for the safety of those using it. 


\section{Study Area}

Sokoto River is a river in north-west Nigeria and a tributary of the River Niger. It has its source near Funtua in the south of Katsina State, some $275 \mathrm{~km}$ in straight line from Sokoto. It flows north-west passing Gusau in Zamfara State, where the Gusau Dam forms a reservoir that supplies the city with water. Further downstream the river enters Sokoto State where it passes by Sokoto and is joined by the Rima River, then turning south and flowing through BirninKebbi in Kebbi State. About 120 kilometers south of BirninKebbi, it reaches its confluence with the Niger River [10]. Sokoto metropolis has distinct weather conditions consisting of wet and dry seasons with mean annual rainfall ranging from $350 \mathrm{~mm}$ to $670 \mathrm{~mm}$ and temperature of $37^{\circ} \mathrm{C}-40^{\circ} \mathrm{C}$ during dry season.

\section{Material and Methods}

Physicochemical parameters of water samples collected from six different points on River Sokoto were analysed during January (Dry Season) and August (Wet Season) months of the year 2014. The samples were collected inairtight plastic containers and transported to the laboratory where they were subjected to different analyses. Temperature and conductivity of the sample were measured using ADWA AD 32, Mauritius. pH: Electronic pH meter (JENWAY 3015)with a combined electrode was used. Known buffer solutions of pH 4 and pH 9 were prepared and used to standardize the equipment and the $\mathrm{pH}$ readings of the water samples were immediately taken. Dissolved oxygen (DO): was determined using Azide modification of Winkler's method [11]. $200 \mathrm{ml}$ of water sample was carefully transferred into a $300 \mathrm{ml}$ BOD bottle. $1 \mathrm{ml}$ of manganese sulphate solution was added followed by $1 \mathrm{ml}$ of alkaline azidade reagent. The resulting mixture was titrated against $0.025 \mathrm{~N}$ sodium thiosulphate to the end point where there was colour change. The titre value was recorded as DO. Biochemical oxygen demand (BOD): was determined using Azide modification of Winkler's method. The procedure in determining dissolved oxygen above was repeated and the DO recorded on day one was named $\mathrm{D}_{0}$. Another BOD bottle was similarly prepared and incubated at $20^{\circ} \mathrm{C}$ for 5 days in the dark. On the completion of 5 days, the bottle was decanted of water and to the precipitate was added $2 \mathrm{ml}$ of orthophosphoric acid. This was shaken gently and titrated with sodium thiosulphate to the end point where there was change in colour. The titre value was recorded as dissolve oxygen on day five $\left(\mathrm{D}_{5}\right)$. BOD was then calculated as difference between the dissolve oxygen on day one and that on day five. Chemical oxygen demand (COD): was determined as described in Standard Methods [11]. To $50 \mathrm{ml}$ of the water sample in a reflux flask was added $10 \mathrm{ml}$ potassium dichromate solution with $1 \mathrm{~g}$ mercuric sulphate and thoroughly mixed. Four sterile glass beads were added to control the boiling of the solution. $10 \mathrm{ml}$ concentrated sulphuric acid containing silver sulphate was added carefully through the open end of the condenser and mixed by swirling. The reflux apparatus was ran for 1 hour and allowed to cool. The flask was removed and its content diluted to $150 \mathrm{ml}$ with distilled water. To the resulting solution was added 3 drops of ferroin indicator. This was titrated with standard ferrous ammonium sulphate to an end point where blue-green colour just changed to reddish-brown. A blank with $50 \mathrm{ml}$ distilled water in place of water sample was treated equally and the chemical oxygen demand (COD) was then calculated. Total solid: The initial weight $\left(\mathrm{W}_{1}\right)$ of an evaporating dish was measured using a laboratory digital balance (Adams, USA) before heated in a hot air oven at $105^{\circ} \mathrm{C}$ for 1 hour and cool in a desiccator. $100 \mathrm{ml}$ of water sample was added into the dish and boiled over a steam bath to dryness. The residue in the dish was further heated for one hour in an oven at $105^{\circ} \mathrm{C}$, cooled and weighed until successive weighing gave the same result and this was recorded $\left(\mathrm{W}_{2}\right)$. Total solid in the sample was calculated using $\left(\mathrm{W}_{2}-\mathrm{W}_{1}\right) \times 100 \mathrm{mg} / \mathrm{l}$. Total suspended solid: Whatman filter paper rinsed in distilled water was dried in an oven at $105^{\circ} \mathrm{C}$ for one hour and cooled in a desiccator. Its weight $\left(\mathrm{W}_{1}\right)$ was determined using a weighing digital balance. $100 \mathrm{ml}$ of water sample was filtered through the paper and dried at $105^{\circ} \mathrm{C}$ for one hour. The weight $\left(\mathrm{W}_{2}\right)$ of filter paper containing the residue was recorded and the total suspended solids calculated using $\left(\mathrm{W}_{2}-\mathrm{W}_{1}\right) \times 100 \mathrm{mg} / \mathrm{l}$. Total dissolved solid: Amount of dissolved solids of the water sample was determined by subtracting the values of the suspended solids from the corresponding total solids of the samples. Alkalinity values: were determined by titration methods (APHA, 1998). To $50 \mathrm{ml}$ of the water samples in clean $150 \mathrm{ml}$ conical flask were added 3 drops of phenolphthalein indicator. The samples were titrated with $0.05 \mathrm{M} \mathrm{H}_{2} \mathrm{SO}_{4}$, until the colour disappeared. To the colourless solution, 3 drops of methyl orange indicator were added and titrated further until the colour change from yellow to permanent reddish or orange red colour and the titre values were recorded and used to compute the alkalinity. Total hardness: The water sample 
was thoroughly shaken and $25 \mathrm{ml}$ was taken and diluted to $50 \mathrm{ml}$ with distilled water. $2 \mathrm{ml}$ of Phosphate buffer solution was added to bring the $\mathrm{pH}$ of the water sample to 10 . Three drops of eriochrome black indicator was also added. This was titrated with $0.01 \mathrm{~mol} / \mathrm{L}$ EDTA to a blue colour end point. Hardness was then calculated as in APHA, 1998. Chloride values: were determined by argentometric method (APHA, 1998). $1 \mathrm{ml}$ of potassium chromate indicator were added into $50 \mathrm{ml}$ of water sample and titrated with silver nitrate solution, until a brick red colour appeared. The blank titration was also carried out. Sulphate values: were determined by Gravimetric/ Turbidimetric method using $\mathrm{Bacl}_{2}$ as precipitant. $50 \mathrm{ml}$ of the sample were measured into a $250 \mathrm{ml}$ beaker, and diluted to $150 \mathrm{ml}$ with distilled water. $1 \mathrm{ml} \mathrm{HCl}$ (concentrated) and 4 drops of methyl orange indicator were added. $10 \mathrm{ml}$ of $10 \%$ Barium chloride solution were added and then boiled for 5 minutes. These were left overnight and then filtered using filter-paper. Distilled water was used to rinse the filter paper to make it free from chloride. The filter paper was dried at $80^{\circ} \mathrm{C}$ in an oven, ignited at $800^{\circ} \mathrm{C}$ in a furnace (Lenton furnaces, England) for 1 hour, cooled in a desiccator and weighed. The igniter cooling and weighing were repeated to give constant value. Sulphate content of the water sample was then calculated. Phosphates: were determined by colorimetric method. To $2 \mathrm{ml}$ aliquot of the water sample in a $25 \mathrm{ml}$ volumetric flask was added one drop of phenolphthalein indicator followed by $2 \mathrm{ml}$ of ammonium molybdate and then $1 \mathrm{ml}$ of freshly diluted stannous chloride solution. These were made up to $25 \mathrm{ml}$ volume with distilled water and mixed thoroughly. After 5 - 6 minutes and before 20 minutes, the colour intensity (absorbance) was measured at a wavelength of $660 \mathrm{~nm}$ in a Spectrophotometer (OPTIMA SP 300, U.K.). Nitrate and Ammonia: were determined by modified Kjeldahl method [12]. For nitrate, $50 \mathrm{ml}$ of water sample and $4 \mathrm{ml}$ of salicylic acid/sulphuric acid were added in the digestion flask and swirled thoroughly to achieve homogenous mixture. $0.5 \mathrm{~g}$ of sodium thiosulphate was added and the mixture was heated cautiously until frothing has ceased. $1.1 \mathrm{~g}$ of potassium sulphate catalyst mixture was added and heated until the digestion mixture became clear. The mixture was boiled for up to 2 hours. It was ensured the temperature did not exceed $400^{\circ} \mathrm{C}$. The digested mixture was allowed to cool and $20 \mathrm{ml}$ distilled water was added slowly while shaking. $10 \mathrm{ml}$ of boric acid was added, diluted with $20 \mathrm{ml}$ distilled water and the flask was placed under the condenser of the distillation apparatus. $20 \mathrm{ml}$ of sodium hydroxide was added through the funnel of the apparatus. About $50 \mathrm{ml}$ of condensate was distilled and a few drops of Boric acid indicator added. This was titrated with $0.01 \mathrm{~mol} / \mathrm{L}$ sulphuric acid to a violet end point. The titre values were recorded and used to calculate nitrate content. Ammonia values were similarly determined without adding Potassium sulphate catalyst mixture.

\section{Results and Discussion}

Physicochemical parameters of water samples from six different points on River Sokoto during dry and wet seasons are presented in Table 1 and Table 2 respectively. The $\mathrm{pH}$ values in water samples were generally alkaline during the dry season in all the sampling points and generally slightly acidic during rainy seasons with the exception of P4 which was neutral. This can be as a result of increased water level during rainy season. The highest value recorded for dissolved oxygen (DO) in both seasons was $1.7 \mathrm{mg} / \mathrm{l}$ which agrees with standard for natural waters $(<8 \mathrm{mg} / \mathrm{l})$. The Biochemical oxygen demand (BOD) highest value $(2.13 \mathrm{mg} / \mathrm{l})$ in both seasons was relatively low compare with WHOs standard of $7.0 \mathrm{mg} / \mathrm{l}$. Low oxygen in water negatively impacts the lives of low oxygen intolerant aquatic organisms such as fish. Higher values obtained in Conductance and Chemical oxygen demand (COD) in the dry season compare with rainy season may be as a result of decrease in rainfall with resultant increase in concentration of electrolytes and other elements in the river water. The total hardness is the total soluble magnesium and calcium salts present in the water expressed as $\mathrm{CaCO}_{3}$. In most natural water the predominant ions are those of bicarbonates associated mainly with calcium to lesser degree with magnesium and still less with sodium and potassium [13]. While there was general failure in all the water samples during the rainy season, two (P4 and P5) out of six water samples failed the total hardness test during the dry season with values above permissible limit of $170 \mathrm{mg} / \mathrm{l}$. Total dissolved solids (TDS) and Total suspended solids (TSS) values were well within the permissible limits of $2000 \mathrm{mg} / \mathrm{l}$ and $1700 \mathrm{mg} / \mathrm{l}$ respectively. In the rainy season, the TSS value was high due to floating materials like fine silt carried by rainwater.

The concentrations of nutrients such as sulphate, Phosphate, nitrate, ammonia and chloride in the water samples were also determined. Sulphate and phosphate levels of the water samples were found to be within permissible limits of $250 \mathrm{mg} / \mathrm{l}$ and $7 \mathrm{mg} / \mathrm{l}$ respectively while nitrate levels were above the permissible limit of 0.1 $\mathrm{mg} / \mathrm{l}$ in both seasons. The cause of high level of nitrate may be as a result of extensive farming taking place at the bank of the river with the possibility of the farmers making use of fertilizers. Chloride levels of the water 
Table 1. Physicochemical properties of water samples from different sites of River Sokoto in January, 2014 (Dry Season).

\begin{tabular}{|c|c|c|c|c|c|c|}
\hline \multirow{2}{*}{ Parameter } & \multicolumn{6}{|c|}{ Values at Sampling Sites } \\
\hline & $\mathrm{P} 1$ & P2 & P3 & P4 & P5 & P6 \\
\hline $\mathrm{pH}$ & 8.11 & 8.06 & 8.05 & 8.37 & 8.50 & 8.02 \\
\hline Temperature $\left({ }^{\circ} \mathrm{C}\right)$ & 25.4 & 25.5 & 25.3 & 25.6 & 25.4 & 25.4 \\
\hline Conductance $(\mu \mathrm{s} / \mathrm{cm})$ & 74.6 & 96.7 & 75.6 & 201.0 & 321.0 & 96.4 \\
\hline D. O. (mg/L) & 1.7 & 1.0 & 1.2 & 1.2 & 0.7 & 0.9 \\
\hline B. O. D. (mg/L) & 0.7 & 0.4 & 0.5 & 0.3 & 0.2 & 0.4 \\
\hline C. O. D. (mg/L) & 30 & 150 & 180 & 230 & 220 & 230 \\
\hline Total Solids (mg/L) & 630 & 580 & 770 & 250 & 400 & 680 \\
\hline TDS (mg/L) & 160 & 190 & 300 & 150 & 260 & 250 \\
\hline TSS (mg/L) & 470 & 390 & 470 & 100 & 140 & 430 \\
\hline Alkalinity (mg/L) & 22 & 21 & 23 & 28 & 71 & 11 \\
\hline Acidity (mg/L) & 15 & 25 & 20 & 5 & 10 & 15 \\
\hline Chlorides (mg/L) & 55 & 35 & 40 & 100 & 50 & 75 \\
\hline Sulphate (mg/L) & 220 & 190 & 180 & 195 & 200 & 210 \\
\hline Phosphate (mg/L) & 0.11 & 0.51 & 0.24 & 0.15 & 1.77 & 0.59 \\
\hline Hardness (mg/L) & 161.6 & 121.2 & 151.5 & 282.8 & 184.8 & 131.3 \\
\hline Nitrates (mg/L) & 19.7 & 9.8 & 6.6 & 10.3 & 11.8 & 12.7 \\
\hline Ammonia-N (mg/L) & 0.46 & 0.28 & 0.35 & 0.62 & 0.84 & 0.35 \\
\hline
\end{tabular}

Table 2. Physicochemical properties of water samples from different sites of River Sokoto in August, 2014 (Rainy Season).

\begin{tabular}{|c|c|c|c|c|c|c|}
\hline \multirow{2}{*}{ Parameter } & \multicolumn{6}{|c|}{ Values at Sampling Sites } \\
\hline & $\mathrm{P} 1$ & $\mathrm{P} 2$ & P3 & $\mathrm{P} 4$ & P5 & P6 \\
\hline $\mathrm{pH}$ & 6.24 & 6.32 & 6.36 & 7.23 & 6.80 & 6.84 \\
\hline Temperature $\left({ }^{\circ} \mathrm{C}\right)$ & 29.1 & 29.0 & 28.2 & 29.0 & 29.2 & 28.8 \\
\hline Conductance $(\mu \mathrm{s} / \mathrm{cm})$ & 470.0 & 100.0 & 90.0 & 510.0 & 120.0 & 80.0 \\
\hline D. O. (mg/L) & 0.09 & 0.07 & 0.08 & 0.09 & 0.07 & 0.10 \\
\hline B. O. D. (mg/L) & 0.21 & 0.27 & 0.20 & 0.35 & 2.13 & 0.28 \\
\hline C. O. D. (mg/L) & 48 & 1008 & 480 & 32 & 688 & 720 \\
\hline Total Solids (mg/L) & 1100 & 900 & 900 & 300 & 900 & 1100 \\
\hline TDS (mg/L) & 800 & 500 & 500 & 100 & 500 & 400 \\
\hline TSS (mg/L) & 300 & 400 & 400 & 200 & 400 & 700 \\
\hline Alkalinity (mg/L) & 10 & 8 & 11 & 13 & 13 & 7 \\
\hline Acidity (mg/L) & 20 & 60 & 60 & 20 & 60 & 60 \\
\hline Chlorides (mg/L) & 60 & 60 & 80 & 180 & 110 & 90 \\
\hline Sulphate (mg/L) & 124 & 82 & 82 & 124 & 124 & 82 \\
\hline Phosphate (mg/L) & 0.21 & 0.19 & 0.21 & 0.21 & 0.21 & 0.22 \\
\hline Hardness (mg/L) & 265.9 & 350.4 & 305.6 & 850.3 & 305.4 & 230.5 \\
\hline Nitrates (mg/L) & 14.2 & 12.4 & 8.6 & 28.1 & 24.3 & 10.9 \\
\hline Ammonia-N (mg/L) & 0.82 & 0.64 & 0.98 & 1.20 & 1.10 & 0.86 \\
\hline
\end{tabular}


samples in dry season were within permissible limit of $150 \mathrm{mg} / \mathrm{l}$ whereas in the rainy season, five out of the six sampled water passed the test except P4 with value of $180 \mathrm{mg} / \mathrm{l}$ which is above the permissible limit. The ammonia levels were also found to be above the permissible limit of $0.6 \mathrm{mg} / \mathrm{l}$ in the majority of the sampled water.

\section{Conclusion}

In conclusion, the results showed that water from River Sokoto, having passed majority of the tests, is fit for irrigation and can be used as source water for water treatment plant for drinking water. However, further study is recommended to determine heavy metals and bacterial constituents of the river water to further ascertain its safety.

\section{Acknowledgements}

We are grateful to the entire staff of Agric./Chemistry Laboratory, Usmanu Danfodiyo University, Sokoto for their moral supports, especially Mal Ahmad Modi.

\section{References}

[1] Smitha, P.G., Byrappa, K. and Ramaswamy, S.N. (2007) Physico-Chemical Characteristics of Water Samples of Bantwal Taluk, South-Western Karnataka, India. Journal of Environmental Biology, 28, 591-595.

[2] Adeyeye, E.I. (1994) Determination of Trace Heavy Metals in Illisha Africana Fish and in Associated Water and Soil Sediments from Some Fish Ponds. International Journal of Environmental Study, 45, 231-240. http://dx.doi.org/10.1080/00207239408710898

[3] Adefemi, S.O. and Awokunmi, E.E. (2010) Determination of Physico-Chemical Parameters and Heavy Metals in Water Samples from Itaogbolu Area of Ondo-State, Nigeria. African Journal of Environmental Science and Technology, 4, 145-148.

[4] Misra, S.G. and Dinesh, D. (1991) Soil Pollution. Ashing Publishing House, New Delhi.

[5] Fakayode, S. and Onianwa, P. (2002) Heavy Metal Contamination of Soil, and Bioaccumulation in Guinea Grass (Panicum maximum) around Ikeja Industrial Estate, Lagos, Nigeria. Environmental Geology, 43, 145-150. http://dx.doi.org/10.1007/s00254-002-0633-9

[6] Fakayode, S.O. (2005) Impact Assessment of Industrial Effluent on Water Quality of the Receiving Alaroriver in Ibadan Nigeria. African Journal of Environmental Assessment and Management, 10, 1-13.

[7] Sangodoyin, A.Y. (1995) Characteristics of Control of Industrial Effluents-Generated Pollution. Environmental Management and Health, 6, 15-18. http://dx.doi.org/10.1108/09566169510091921

[8] Sangodoyin, A.Y. (1991) Groundwater and Surface Water Pollution by Open Refuse Dump in Ibadan, Nigeria. Journal of Discovery and Innovations, 3, 24-31.

[9] Ajayi, S.O. and Osibanji, O. (1981) Pollution Studies on Nigeria Rivers, II: Water Quality of Some Nigerian Rivers. Environmental Pollution Series B, Chemical and Physical, 2, 87-95.

[10] Hartenbach, A. and Schuol, J. (2005) Bakolori Dam and Bakolori Irrigation Project-Sokoto River, Nigeria. Americ. J. Pub. Health, 76, 407-410.

[11] APHA (1998) Standard Methods for the Examination of Water and Wastewater. 20th Edition, Washington DC.

[12] Bremner, J.M. and Mulvaney, C.S. (1982) Methods of Soil Analysis. In: Page, A.L., et al., Ed., 2nd Edition, Part 2, Agron Monograph 9, Madison, 595-624.

[13] Khan, R.M., Jadhav, M.J. and Ustad, R. (2012) Physicochemical Analysis of Triveni Lake Water of Amravati District in (MS) India. Bioscience Discovery, 3, 64-66. 